\title{
Train to Pakistan: A Saga of Unsalvaged Suffering
}

\author{
Dr. Alka Bansal \\ Head, Dept. of English \\ S.D. (PG) College \\ Muzaffarnagar, Uttar Pradesh, India \\ dr.alka.sdc@gmail.com
}

\begin{abstract}
The torments of the colossal human tragedy of the partition of India and its aftermath are still being borne by the people of India in some way or the other. The fissured social and emotional spirit of the people is still not healed. The horrific scenes of partition still haunt the psyche of the Indians. Millions were massacred and those that were alive were like live corpses moving around. Their sufferings are unfathomed. They not only suffered physically but also mentally and emotionally. Khushwant Singh's Train to Pakistan is a novel that unfolds all aspects of suffering and pain which were endured by the people at that time. Singh has been successful in communicating to his readers the tribulations of the partition days, the harrowing experiences, grossness, the madness and the bestial horrors.The displacement of people from one country to another became the root cause of the whole holocaust. The village which bustled with activity turned into a kenopsia. Singh's rankling at the idea of partition can be perceived in the novel. In the novel, Singh has vehemently written about every aspect of the dreaded violence to which women were subjected. It is quite obvious from the conditions prevailing in India that this splitting of the country was a futile effort. It sowed the seeds of communal discord permanently. People are still suffering they have not fully
\end{abstract}


recovered from this psychosomatic trauma. The seeds of harmful weeds that were sown by the partition are still being reaped by the Indians.

Keywords: Suffering, Partition, Displacement, Violence, Anxiety, Loss, Trauma, Horror, Mutilation

The cataclysmic partition of India in 1947, witnessed the epitome of human sufferings in the form of massacres; mutilation of human bodies; migration; uprootedness; sexual assaults; loss of relations, honour, property, mental peace, sense of security, ethnicity, identity and much more. History books and chronicles have not expressed the feelings and emotions of the people, they have recorded the data and facts related to the process of partition. The actual trauma experienced by the people finds a poignant reflection in the literature of that period and is mentioned to date in Indian Literature. It has left an indelible impression on the sensitive minds and souls of the persons who were inflicted directly or indirectly by the heart-rendering experiences of partition days. The throes of partition are not easy to be erased from the memories of Indians especially the people of Punjab and West Bengal.

In 1947, India achieved Independence from the age-old yoke of British rule. But the mirth of independence had soon deluged into the misery of partition. The independence of India from British rule brought in its wake the partition of British India into two countries: India and Pakistan. The hearts that were joyfully singing the song of independence started whining the mournful elegy of partition. The country was divided on religious lines. Pakistan became a principally Muslim state and India remained secular. The political leaders who lacked acumen and wisdom changed the identities of the people overnight. The religious identities of the people became more distinctly evident and defined. The chasm between the communities of Hindus and Muslim grew wider. The partition warped the light and brightness of freedom into darkness and gloom. The ethnic riots blazed up on both sides of 
the border leading to massive destruction, despair, antagonism and murderous chaos. The whole society was beset by a paroxysm of angst.

The partition of India is not an ordinary historical event that can be buried in the annals of history and forgotten. It is that dark page in the history of India which will continue to haunt the memories of the people for ages. During this holocaust, more than eight million people migrated and approximately one million died. This kind of forced migration and massacre is unprecedented to date. The historical documents can give an account of the dead bodies but cannot communicate the shrilling shrieks of pain borne by the wounded, mutilated bodies and the lacerated souls and psyche. History can never sketch the heinousness and magnitude of the tragedy of partition. Historian, Urvashi Butalia has rightly said that partition "has ramification that reach far beyond 1947, yet historical records make little mention of the dislocation of people's lives, the strategies they used to cope with loss, trauma, pain and violence" (Butalia 5).

It is literature that explores and exhibits the feelings, emotions and sentiments of individuals distinctly. The literary writer describes the experiences and conveys the feelings in such a manner that they go deep into the mind and touch the heart of the readers. Indian literature in many languages, especially Hindu, Urdu, Bengali and English has depicted an authentic picture of the horrifying consequences of the partition. This literature narrates the inner realities of the people; their fears and apprehensions; their feelings of insecurity; their identity crisis; their bereavement; their longing for roots; their sense of honour and their pain and anguish.

Some very emotional and pricking delineations are there in the works of Sadat Hasan Manto, Khwaja Ahmad Abbas, Krishan Chandra, Rajendra Singh Bedi, Sardar Singh Duggal, BhishmaSahani, Amrita Pritam, Yashpal, Nanak Singh, IsmatChugtai, Chaman Nahal, B. Rajan and Khushwant Singh. These works are replete with overwhelming scenes of partition 
and description of the inner psychology of the characters who manage to live during uncertain and trying times. IsmatChugtai's essays "Communal Violence and Literature" (English translation) opens with a shocking description of the aftermath of the partition:

The flood of communal violence came and went with all its evils, but it left a pile of living, dead and gasping corpses in its wake. It wasn't only that the country was split into two bodies and minds were also divided. Moral beliefs were tossed aside and humanity was in shreds (Naqvi 3).

Khushwant Singh's Train to Pakistan, a historical novel also recounts the horrors of the violence that flared up due to the hate and intolerance between the two communities during the days of the partition of India. Singh has portrayed these tumultuous times through the eye view of a small fictional village, Mano Majra situated on the border of India and Pakistan. Singh describes in the novel how the horrendous partition disrupted the placid life of the people of Mano Majra. This village was inhabited by a Hindu family and almost an equal number of Sikhs and Muslims who lived together peacefully and amicably. The story of this village unfolds the realities of partition which have been used as a backdrop in this novel. The distrust, fear, insecurity and hatred which ran unbridled made the amiable neighbours hostile, “The Sikhs were sullen and angry. 'Never trust a Mussulman', they said. The last guru had warned them that Muslims had no loyalties" (Singh 128). This xenophobia, genocide, violence and loss has been graphically captured in Train to Pakistan and narrated in an extremely gripping language.

In this novel, the novelist has captured the quintessence of an Indian village astoundingly. This village Mano Majra is the microcosm of the macrocosm. The plight of common innocent, simple men of the village who had to suffer the brutalities of partition, the pathetic sufferings of meek women, the tossing of people in the different odd situations has been described subtly by Khushwant Singh. Very sarcastically he has condemned the 
partition of India and its repercussions. In this novel, he has endeavoured to excavate a past based on his memories. He wrote this novel in 1956. What he has described in the novel is not a saga of a few characters of Mano Majra but it is the saga of humanity. "Khushwant Singh has however succeeded through resolved limitation and rigorous selection in communicating to his readers a hint of grossness, vastness and utter insanity of the twonation theory and the partition tragedy. The pity and horror of it all" (Iyengar 228). In the novel, Singh has focused more on the communal and patriarchal discourse of the time of partition.

The storyline of Train to Pakistan is seething and emotionally exhausting. It is a witness to the naked dance of the appalling carnage. The most perturbing facet of the partition was that the villagers who were living together in harmony for a very long time suddenly became foes, thirsty for each other's blood. Some imaginary lines divided the masses of India. Salman Rushdie the famous diaspora novelist has aptly said in his novel. The Midnights Children that the subcontinent of India was, "split like an amoeba". Amitav Ghosh in his novel The Shadow Lines also mentions these imaginary lines which divide places. The character Tha'mma is unable to see any lines or trenches dividing India and Bangladesh. The splitting aggravated prejudice and animosity. In this fractioned milieu, men started tearing and snapping wildly like animals on each other and the bonds of human relationships were torn and tattered. Religious tension was the root cause of this violence. Jugga relates to Iqbal and the tongaman, Bhola:

The Bhai told me of a truck full of Baluch soldiers who were going from Amritsar to Lahore. When they were getting near the Pakistan border the soldiers began to stick bayonets into Sikhs going along the road. The driver would slow down near a cyclist or pedestrian, the soldiers on the footboard 
would stab him in the back and then the driver would accelerate away fast. They killed many people like this (Singh 71).

The city dweller boy who had come to the village told the Sikhs of Mano Majra about the treatment which was meted out to the Sikhs and their women. He also told about the trainloads of dead Sikhs and Hindus who were coming to other places. The people of Mano Majra had also seen a train that had come loaded with corpses from Pakistan. The boy instigated the people of the village:

For each Hindu or Sikh, they kill, kill two Mussulmans. For each woman they abduct or rape, abduct two. For each home, they loot, loot two. For each trainload of dead, they send over, send two across. For each road convoy that is attacked, attack two. That will stop the killing on the other side. It will teach them that we also play this game of killing and looting (Singh 57).

When Meet Singh questioned him that why should we kill the Muslims here in revenge for what the Muslims in Pakistan are doing. These Muslims had not committed any crime. At this statement of Meet Singh, the lad looked angrily at Meet Singh and subdued Meet Singh with his argument:

What had the Sikhs and Hindus in Pakistan done that they were butchered? Weren't they innocent? Had the women committed crimes for which they were ravished? Had the children committed murder for which they were spiked in front of their parents? (Singh 157).

Although people like Iqbal Singh (the social worker) exist they are very few, who do not pollute their minds by the venom which the communally charged people spit on others. When Iqbal sees the frenzied crowd outside, he feels feverish he wants to go out and face the maddening and mindless mob and make them aware that what they are indulging in is a grave misdeed. But he is hesitant whether he should go out and tell the mob: 
$[\mathrm{I}] \mathrm{n}$ clear ringing tones that this was wrong-immoral? Walk right up to them with his eyes fixing the armed crowd in frame-without flinching, without turning, like the heroes on the screen who become bigger and bigger as they walk right into the camera. Then with dignity fall under a volley of blows, or preferably a volley of rifle shots. A cold thrill went down Iqbal's spine (Singh 178).

He has a keen desire to suppress this bestial violence and bring a moral change in people, but he knows that this resistance would in turn generate more violence. He suffers from the anxiety of getting killed for no reason, his death would be a futile sacrifice.

Jugga is a character who sacrificed his life at the end of the novel to save his beloved Nooran who was aboard the train which was going to Pakistan loaded with Muslim refugees. The irony of his life is that he was considered a 'badmash' by the whole village but he is the only person who proved to be a true human being. He suffered the stigma of being a dacoits son. He was falsely accused and jailed. Had he not been in jail he would not have let his mother behave with Nooran rudely. He and Nooran would have been happily married. It is the 'badmash' who baulks the plan of the fanatics to kill the people on the train by displaying exemplary courage in cutting the rope which was tied to kill the 'solid crust of human beings on the roof'. In this act this stud bull forfeits his life; "The engine was almost on him. There was a volley of shots. The man [Jugga] shivered and collapsed. The rope snapped in the centre as he fell. The train went over him, and went to Pakistan" (Singh 190).

Train to Pakistan recreates the scenes of the horrific ethnic violence that disfigured the face of humanity. When the ghostly train comes to Mano Majra and halts with a deathly silence, a sense of fear lurks in the atmosphere. The train appeared sinister and ominous. There is an air of kenopsia around the station. The 'shrieking silence' and the putrid smell of the burning dead bodies makes the people shudder and brood, the train had come from 
Pakistan this was enough for them to understand what must have happened. How this affected the psyche of the people can be seen in the restlessness of Hukum Chand. When at night he closes his eyes to rest:

Scenes of the day started coming back in panoramic succession. He tried to squash them by pressing his fingers into his eyes.... There were women and children huddled in a corner, their eyes dilated with horror, their mouths still open as if their shrieks had just then become voiceless (Singh 90). He is completely shattered and suffers from nightmares of communal hatred.

The stark realism and untarnished mode of expression of Singh transport the readers' imagination to the scenes of horror which he has described in the novel. The ghastly and inhuman acts come alive before our eyes sending a shiver down our spines. Here is a heartrending description. After hearing the human cries for help the three men who were assigned the duty of watching the flooding river 'Sutlej' and the lumbardarwent near the river and stood on the embankment. In the darkness of the night, things were not visible properly. They could not make out that something was floating in the river; "it was a dead cow with its belly bloated like a massive barrel and its legs stiffly stretched upward. Then followed some blocks of thatch straws and bundles of clothing" (Singh 149). Then they heard the rumbling sound of a train with no lights and the train did not whistle. This was the second train that had come to Mano Majra loaded with the dead, mutilated bodies. They sat near the river with heavy hearts and in the light of the dawn they could see very conspicuously the:

Carts with bloated carcasses of bulls still yolked to them. Horses rolled from side to side as if they were scratching their backs. There were also men and women with their clothes clinging to their bodies; little children sleeping on their bellies with their arms clutching the water and their tiny buttocks dipping in and out (Singh 150). 
The villagers could deduce that these people had not drowned rather they had been brutally slaughtered. The body of an old peasant was floating which:

had a deep wound on his neck, which slanted down from the side to the chest. A child's head-butted into the old man's armpit. There was a hole in its back... Some were without limbs, some had their bellies torn open many women's breasts were slashed. They floated down the sunlit river, bobbing up and down (Singh 151).

Such hideous descriptions of genocide expose us to the trauma which the people of that time faced. The novel not only describes the physical violence but also sheds light on the mental and psychological trauma which resulted in anxiety, stress, depression, mania and fear psychosis etc. The entire picture is indeed very terrible:

It unfolds the horrible drama of communal violence-the sinking of human values on the mire of communal frenzy. The sight of geckos pouncing on the moth and catching it fluttering in the jam is symbolic of the massacre that was a common figure of those days. It points to the fact how the violent drama of religious butchering was enacted during those terrible days (Haydn 133).

Many incidents in the novel enunciate this mental and psychological suffering. Hukum Chand is sickened with fear psychosis after catching a glimpse of the ghostly train. He also suffers from stress and anxiety related to the well-being of Haseena and the people of the village. He "looked like a tired man. One week had aged him beyond recognition" (Singh 163). Other characters in the novel like Imam Baksh, Meet Singh also suffer from anxiety and fear. Hukum Chand also felt miserable because of the pricks of his conscience; "he felt a pang of remorse. He also knew that his remorse and good resolutions went with the hangover. They always did. He would probably drink again and get the same girl over and sleep with her - and feel badly about it. That was life, and it was depressing" (Singh 100). 
One extreme example of mania and depression is of Sunder Singh, a brave Sikh soldier, who was granted land in Sindh by the government. He was going by train with his wife and three children. The train in which they were travelling was detained at the station for four long, hot days. The passengers were not allowed to onboard the train. Sunder Singh's children felt hungry and thirsty. They kept on crying for water, Sunder Singh had no other option but to serve them his urine. But after some time that also tried and the crying sound unnerved Sunder Singh and "he pulled out his revolver and shot them all" (Singh 187).

The plight of women who suffered the brutalities of violence has been described fervidly by Singh in Train to Pakistan. The women were the worst sufferers. They suffered because of their smothered and fettered existence. They were suppressed, oppressed and victimized. They were powerless so they had no power of resistance. The inhuman violence inflicted upon the meek women rendered them lifeless. The dehumanising sexual violence ended their existence, even if they were alive, they were mere puppets of flesh and blood without any soul. The novel is replete with descriptions of violence against women. Women of all ages were brutally raped, assaulted, mutilated and abducted to be used as a sex toy to gratify sexual desires and humiliate the other community. They were also paraded naked on the streets. To save their honour many women immolated themselves or jumped into the wells or became a victim of honour killing.

The novel also relates the brutal ordeal of Sundari, the young, newly married daughter of Hukum Chand's orderly. She had been married just four days ago to Mansa Ram who worked in Gujranwala as a peon. The crowd of relatives had not allowed their privacy to meet each other. Sundari had hardly seen him properly. They both sat in a bus going to Gujranwala with all hopes of a happy married life. The red lacquer bangles and the attractive henna patterns on her palms were still deep red. She was daydreaming about how she would be loved by her husband but suddenly all her hopes and desires are crushed to bits when a 
huge crowd of people stopped the bus and ordered the passengers to come out. The Sikhs were hacked to death and she who had not even seen her hundred's face properly:

[W]as shown her husband completely naked. They held him by his arms and legs and one man cut off his penis and gave it to her. The mob made love to her. She did not have to take off any of her bangles. They were all smashed as she lay in the road, being taken by one man and another and another (Singh 197).

What could have been more brutal and gruesome than this to this young, Sundari!

There were many such women like Sundari who suffered profoundly because of the savagery that wreaked havoc on their lives. The sexual assaults brought shame and dishonour to them, their family and their community. The word 'izzat' (honour) has strong sexual connotations associated with womanhood. The honour of a woman was associated with the honour of the community. It could save or taint the glorious image of the community. This was the reason why men abused women of the other community. Abducted women were not accepted by their family and community in India, due to the fear of this social stigma. To evade this situation the women who were victims of sexual violence either did not go back home or committed suicide. In the novel also there are references to this code of society. Many women jumped into wells or set themselves ablaze. After undergoing such excruciating mental and physical torture their death was a mercy to them. The unspeakable misery and torments which the women endured and suffered during this devastating sexual violence cannot find a befitting pronouncement in black and white.

The emotional sufferings of the characters of the novel are no less than their physical sufferings. The feeling of loss led to critical emotional distress. During partition, people suffered economic loss, loss of loved ones, loss of identity, loss of roots, loss of honour, loss of faith etc. displacement was a major cause of emotional despair because when people are 
displaced and alienated, they suffer agony. When the Muslims had to leave Mano Majra to move to refugee camps woefulness was writ large on their faces. The novelist has described the deserted look of their houses; "their deserted houses with doors swinging wide open had acquired an eerie haunted look" (Singh 153). They had one night's time to pack up and leave their homes. Imam Baksh said, "it has taken our fathers and grandfathers hundreds of years to make" (Singh 135). His sad statement was an outcome of a deep dolour and sentimental shock.

Hukum Chand is emotionally involved with Haseena and her separation troubles him. He feels anxious about her safety. Meet Singh and almost all the people, Hindus as well as Muslims feel sad at the time of separation. "They wiped the tears off their faces and turned back to their homes with heavy hearts" (Singh 145). Later when Jujja comes to know that Nooran is in the refugee camp and will go to Pakistan he cannot bear it. The thought of separation from Jugga twinges the heart of Nooran. She goes out on the rainy night to meet Jugga's mother (Jujja was in custody). Nooran does not want to go anywhere, she wants to marry Jujja and give birth to Jujja's child which she is carrying in her womb. She pleads to his mother to inform Jujja so that he can rescue her from the refugee camp at Chunddannugger. The scene of Nooran's separation is pitiful.

The feeling of alienation is another kind of suffering that these characters undergo. The ones who were leaving India and going to Pakistan were perplexed. Imam Baksh is sad at the thought of leaving his village and his ancestor's home. When he asks the lambardar what the people of the village have decided for them (Muslims), lambardar replies, "This village is your village as much as ours..." Imam Baksh wiped a tear from the corner of his eyes and blew his nose in the hem of his shirt... "What have we to do with Pakistan? We are born here. So were our ancestors, we have lived amongst you as brothers" (Singh 133). On 
the other hand, the Hindus who had run from Pakistan felt lost in this new land, India because the land which they were forced to leave was their native land.

Thus, it is discerned that much of the tragedy grew from the displacement during partition. The whole society was reshaped, identities were thwarted, aggressive, chauvinism based on religious identity came forth, intolerance and fanatism were rampant. All this was instrumental in augmenting and aggravating the sufferings of the human lot. Train to Pakistan revives the perturbing wounds of partition in post-colonial India. Singh has not depicted the events in the novel with a political angle but has provided human facets that transcribe the perception of genuineness apprehension and integrity. He has ended the novel on an optimistic note that humanity is not completely dead. Even a blackballed character like Jugga can bring a ray of hope and life for the disconsolate and distressed souls. Singh's art "is a creative endeavour of transcending the actual, asserting the value and dignity of the individual and finally, of expressing the tragic splendor of man's sacrifice for a woman" (Sahane 52).

The novel Train to Pakistan encapsulates the colossal human tragedy of partition which still lurks in the memories of the people. Millions of people who had to realign identities are still suffering. Those who had to start their life all over again from the scratch suffer from the nostalgia for the loss of home, country, friends and relatives. People are still bearing agonies stemming from the troublesome nostalgia of things left and lost. The ruination, the bloodbath and "heaps of crushed humanity" cannot be forgotten easily. This suffering is our cultural heritage. The symptoms of this historical trauma will continue to pass from generation to generation along with the emotional baggage. It is ingrained in the collective unconsciousness. Their hearts are splintered. Their fractured spiritskeep oscillating between India and Pakistan. Many families are still struggling to cope with post-traumatic stress disorder. The people suffer from things that happened in the past and from fear of 
future happenings. Almost seventy-four years have passed but the wound of partition has not been healed properly. Thus, the suffering remains unsalvaged.

Literature has kept the shocking memories of partition alive in our minds. The startling narratives of many writers from the time of partition till today mention this catastrophic episode. This itself proves that the Indians have not recovered from the trauma. It has been aptly said that; "The rending of the social and emotional fabric that took place in 1947 is still far from mended" (Menon 91). This suffering is a state which has enveloped our psyche and seems incurable. The existential angst is sustained leading to never-ending problems. "Today the legacy of 1947 looms larger than ever before on the subcontinent. Partition has actually proved to be a trauma from which the subcontinent has never fully recovered. But sadly, this is not reflected in its history writings, a fact that is lamented by many" (Roy 18). 


\section{Works Cited}

Butalia, Urvashi. The Other Side of Silence: Voices from the Partition of India. NewDelhi: Viking Press, 1998.

Haydn, Moore Williams, "Khushwant Singh and the Sikhs", Studies in Modern Indian Fiction in English. Calcutta: A Writers Workshop Publication, 1973.

Iyengar, K.R. Srinivas, "Recent Indo-English Fiction”, The Arya Path, Vol. XXIX, No. 5, May 1958.

Menon, Ritu. Borders and Boundaries: How Women Experienced the Partition of India. New Jersey: Rutgers Univ. Press, 1998.

Naqvi, Tahira. (Trans.) IsmatChugtai’s My Friend, My Enemy: Essays, Reminiscences, Portraits. New Delhi: Kali for Women, 2001.

Roy, Rituparna. South Asian Partition Fiction in English: From Khushwant Singh to Amitav Ghosh. Amsterdam: Amsterdam University Press, 2010.

Shahane, Vasant A. "The Novel as Realistic Epic: Train to Pakistan". Published in Three Contemporary Novelists, edited by R.K. Dhawan. New Delhi: Prestige Press, 1992. Singh, Khushwant. Train to Pakistan. Time Books International, 1989. 